\title{
Evaluation of Investment Impact on Port Efficiency: Berthing Time Difference as a Performance Indicator
}

\author{
Bayram Bilge SAĞLAM, Abdullah AÇIK, Egemen ERTÜRK \\ Dokuz Eylül Üniversitesi, Denizcilik Fakültesi, Türkiye \\ bayram.saglam@deu.edu.tr; ORCID ID: orcid.org/0000-0003-4977-1634 \\ abdullah.acik@deu.edu.tr; ORCID ID: orcid.org/0000-0003-4542-9831 \\ egemen.erturk@deu.edu.tr; ORCID ID: orcid.org/0000-0002-4442-6674
}

\begin{abstract}
Highly competitive nature of port business environment puts heavy pressure on port operators on performance related issues. In order to be competitive, after all the other strategic moves are exhausted, what is left is to improve the performance of a port by means of increasing the number of vessels calling the port. One way to achieve this goal is to minimize the time spent at port for each vessel. Using the data envelopment analysis (DEA) method to evaluate its efficiency, this paper analyzes a port which made investments in order to improve this issue with berthing time difference (BTD) as the output. The results show that DEA method can be a valuable tool for port operators in evaluating the efficiency of their investments.
\end{abstract}

Keywords: Port Efficiency, Port Investment, Port Time, Data Envelopment Analysis.

\section{Yatırımların Liman Verimliliği Üzerine Etkisinin Değerlendirilmesi: Bir Performans Göstergesi Olarak Yanaşma Zaman Farkı}

$\ddot{O} z$

Liman işletme çevresinin rekabetçi doğası, liman işletmecilerine performans ile ilgili hususlarda bir baskı unsuru olușturmaktadır. Rekabetçi avantajı elde etmek adına, stratejik olarak yapılabilecek hamleler tükendiğinde, geriye kalan tek seçenek limana uğrayan gemileri artırma yolu ile liman performansını yukarı çekmektir. Bu hedefe ulaşmanın bir yolu her bir geminin limanda kaldığı süreyi minimuma indirmektir. Bu çalışma, veri zarflama analizi (VZA) ile, bu hususu geliştirmek için yatırım yapmış bir limanı, çıktı olarak yanaşma zaman farkını (YZF) kullanarak analiz etmektedir. Sonuçlar VZA'nın liman işletmecileri tarafından yatırımlarının değerlendirilmesinde önemli bir araç olarak kullanılabileceğini göstermektedir.

Anahtar Kelimeler: Liman Etkinliği, Liman Yatırımı, Liman Süresi, Veri Zarflama Analizi. 
The maritime trade has always mirrored the global economy and can almost be deemed an indicator of it. The lingering decrease in the world trade made the already cut-throat port industry even more competitive. The severity of the circumstances becomes clearer in the competition of ports in the same region or even the same country [1]. While other factors such as hinterland and proximity to industry/consumer is on the same level, and considering the port fees would be almost identical, all that is left to make a difference is the port efficiency. In order to gain a competitive edge, slightest it might be, port authorities plan, strategize and implement both infrastructural and superstructural investments, and as to compare with their competitors, majority use the cargo throughput figures. Port efficiency has been thoroughly researched in the literature, for multiple reasons including the above mentioned ones. However, while cargo throughput seemingly was the main focus in most of such researches, it is merely a fracture, when one considers the port functions as a whole. While the cargo throughput is an important performance indicator in port authorities' point of view, time the vessel spends at the port is one of the more important criteria when it comes to port selection for shipowners. The time spent at port not only means more costs for the shipowner, but also can create bottlenecks in the supply chain process $[2,3]$. Thus the expectations of the port users regarding the port time results in a pressure that is put on the port authority. To overcome this pressure, port authorities are forced to implement infrastructural or superstructural developments besides carrying out effective operational planning.

In the light of this information, this study focuses on time spent at port as a performance indicator. As Data Envelopment Analysis (DEA) analyzes efficiency by comparison with the best practice, it has been increasingly used as an efficiency measurement tool [4]. This paper aims to evaluate the effects of port investments and resource assignments on average time that a vessel spends in port between the actual berthing time and the requested berthing time.

The majority of researches regarding the port efficiency considers cargo throughput as the sole output, only a small number of researches considers different aspects of port efficiency eg. $[5,6,7,8,9]$. Even when it is considered as an output, port time related outputs include the whole time that a vessel spends in port without distinguishing the waiting caused by parties other than the port. This papers originality comes from the fact that the authors chose to analyze the time that the port actually has control over, which can be seen as a true indicator of performance.

The structure of the paper is as follows: In the first section of this paper, the related literature is reviewed based on the different DEA methodologies and aims on port efficiency. In the second section, the applied methodology and the data used are explained and finally in the third section the results are discussed and some suggestions are made on the matter of reducing port time.

\section{Literature Review}

In today's competitive port industry conditions, the importance of port efficiency is becoming increasingly obvious. Whilst the usage of DEA method in port efficiency measurement is becoming widespread, researches are greatly varied not only by their aim, but also with their sample, methodological approaches and input/ output selections.

In this body of literature, the study of Roll and Hayuth [10] appears to be the initial attempt that applies DEA to the port industry. However, as the data of the study were hypothetical, the authors aim 
is only to point out the usefulness of DEA for measuring the port efficiency. This research can be considered as a kickstarter for the application of DEA method in port efficiency measurement researches with differing aims.

The main aim in the majority of the researches have been determining the sources of inefficiency in order to indicate possible improvements to be made regarding port efficiency. Although these studies approach the matter in the same aim, their samples and input/output selections for evaluating efficiency differs. Among these researches, some of them took it a step further and carried out benchmark analysis as well [11, 12, 13, 14, 15]. By doing so, the findings of these researches have provided valuable information for the inefficient ports by indicating the efficient ports which they should emulate.

Apart from that, the relation between the efficiency and the size of the terminal have been important research question in the literature. However, the related studies revealed that the size is not a determining factor for port efficiency aimed to explore whether there is a relation between port ownership and efficiency but it is found that no relationship exists between them $[15,16,17]$.

The differences between the aims of the port efficiency studies resulted in various methodological approaches as well. In his study, Itoh [18] focused on 8 major container ports in Japan and applied window analysis in order to determine the efficiency changes in 9 years period. Similar to Itoh [18], Al-Eraqi et al. [19] performed both standard DEA models namely CCR, BCC and window analysis together in their research and gained larger details on performance analysis of main seaports in the Middle Eastern and African countries.

So et al. [20] aimed to measure the relative efficiency of major container ports in the Northern Asia and identified the sources and degrees of inefficiency. This study distinguishes itself from the others by applying super-efficiency model apart from standard DEA models. By doing so, the study makes a further investigation on the efficient DMUs and measures how much the inputs can be increased while not become inefficient. In resemblance, Ablanedo-Rosas and Ruiz-Torres [13] used super-efficiency model and examined 29 Mexican ports by providing the ranking of the efficient decision making units (DMUs).

Beside the above mentioned researches, there have been some interesting studies with their unique and/or pioneering methodological approaches. Lin and Tseng [6] applied slack variable analysis to reveal the potential areas that needs to be improved for altering the inefficiencies. Following this, a sensitivity analysis is conducted to identify the weights of the inputs and outputs in terms of their effect on the efficiency. $\mathrm{Ng}$ and Lee [7] evaluated the efficiency of major Malaysian container ports both with cross-sectional and panel data analysis. Different from others, this paper added a port (Port of Singapore) which is not originally involved in the sample in order to gain an advantage of providing a reference point. To identify the potential sources of inefficiencies, Min and Park [8] proposed a hybrid DEA/simulation model and measured capacity utilization and throughput efficiency of selected container ports.

When studies similar to this one that focus on Turkish container terminals are analyzed, it's seen that they vary in sample selections; methods applied and input/ output selections. Ateş and Esmer [21] linked DEA with Malmquist Total Factor Productivity Index in order to analyze the effects of 2009 global financial crisis on 13 Turkish container terminals. With a broader sample including 16 Turkish container terminals, Ateş and Esmer [22] applied various DEA models, namely; CCR, 
BCC and super efficiency along with Free Disposal Hull method, which is another relative efficiency measurement tool. While these two studies analyze TEU throughput as the sole output, in the researches of Güner $[23,24]$, the scope of the efficiency analysis was widened as the outputs also include additional performance indicators such as number of ships and total revenue.

The common ground of the reviewed literature is that each of the studies compares different ports as DMU's and rarely use other model outputs than TEU throughput. This research differs in both of the above mentioned matters by i) applying the longitudinal data of a single port as DMU's, ii) analyzing BTD as an output measure considering its importance as a key performance indicator.

\section{Methodology}

DEA is one of the most commonly used non-parametric mathematical programming technique which is developed by Charnes et al. [25]. It is based on an efficiency concept which was originally introduced by Farrel [26]. In this concept, efficiency frontiers are constructed and homogenous DMUs are used to estimate relative efficiencies. Any unit on the frontier is considered efficient and the units positioned below the frontiers are considered inefficient.

The most popular DEA models are the CCR and BCC models. The original model of DEA is CCR which is mathematically modeled by Charnes et al. [25]. It assumes constant return to scale relationship between inputs and outputs. The BCC model which is introduced by Banker et al. [22] assumes variable returns to scale.

The initial CCR output - oriented model (in envelopment form), can be stated as follows:

$$
\operatorname{Max} \theta_{0}+\varepsilon\left(\sum_{i=1}^{m} S_{i}^{-}+\sum_{r=1}^{s} S_{r}^{+}\right)
$$

Subject to

$$
\begin{array}{lr}
\sum_{j=1}^{n} \lambda_{j} x_{i j}+S_{r}^{-}=x_{i 0} ; & \mathrm{i}=1,2, \ldots \ldots, \mathrm{m} ; \\
\sum_{j=1}^{n} \lambda_{j} y_{i j}+S_{r}^{+}=\theta_{0} y_{r 0}, & \mathrm{r}=1,2, \ldots ., \mathrm{s} ; \\
\lambda_{j}, S_{i}^{+}, S_{r}^{-} \geq 0, \forall j, \quad \mathrm{j}=1,2, \ldots, \mathrm{n} ; 0<\varepsilon<<1
\end{array}
$$

where: $m$ is the number of inputs, $s$ is the number of outputs and $n$ is the number of years (DMUs) used in the evaluation; $\theta_{0}$ is the radial efficiency factor showing the proportional increase in output levels of the year $0 ; \lambda_{\mathrm{j}}$ is the intensity factor showing the contribution of year $j$ in the derivation of the efficiency of year $0 ; x_{i j}$ is the amount of the ith input used by the $j$ th year; $y_{\mathrm{rj}}$ is the amount of the $r$ output produced by the $j$ th year; $\varepsilon$ is a small positive number to ensure that the inputs and the output have at least some weighting in the efficiency measure; and $S_{i}^{-}, S_{i}^{+}$are input and output slack variables.

The efficiency rating of the " 0 " year is given by the index $\mathrm{z}_{0}{ }^{*}=1 / \theta_{0}{ }^{*}$, where $\theta_{0}{ }^{*}$ is the optimal value of the $\theta_{0}$. Years which $\mathrm{z}_{0}{ }^{*}=1$ are characterized as relative efficient or benchmark years, while years for which $\mathrm{z}_{0}{ }^{*}<1$ are lie inside the frontier and characterized as inefficient.

Note that the above original model (CCR) uses constant return to scale, as pointed out previously. Banker et al. [27] extended the above original model to account for the existence of variable return to scale. The variable return to scale model (known as BCC model) can be obtained through the addition of a convexity constraint to model requiring that the multipliers $\lambda_{j}$ add up to $1\left(\sum_{j=1}^{n} \lambda_{j}=1\right)$.

DEA models should be developed in consistency with the research aim. It can be either input reduction or output augmentation. If the main aim is to identify elements that are over-using resources, then input reduction should be the main focus of the application. That means, the 
input oriented model is the appropriate tool for the application. If the aim is output augmentation, then the appropriate analysis tool is an output oriented model [28].

In light of this information, this paper, incorporating data from Mersin International Port (MIP) covering a 6 year period, applies both output-oriented CCR and BCC models. MIP has undergone considerable infrastructural and superstructural investments throughout this 6 year period. This fact makes MIP a fitting selection for the analysis of investments' effect on efficiency. On top of this, MIP is located in a competitor heavy region with other ports which share the common hinterland such as Limak and Assan Port. In this competitive environment, ports' efficiency on reducing "time spent on port" is considered as an important indicator that shapes the port users satisfaction and ship owners' decision making on port selection.

\section{Specification of Input and Output Measures}

One of the more important points when conducting a DEA analysis is determining the input/output variables in accordance with the aim of the research. The specification of variables to be used in the model is critical. Identifying misleading or unfit input or output could lead to biased results and thus inappropriate conclusions [29]. This study, applying an outputoriented model, handles "Berthing Time Difference (BTD)" as the output. BTD is the difference between the actual berthing time and the requested berthing time by the vessel. The purpose behind choosing BTD as an output is the fact that BTD provides more realistic port time measurement as it only includes the time lost caused by the port. In this context, the following can be classified as inputs that may have an effect on BTD as an output: number of berths, berth length, draft (m), number of tugs, number of quay cranes, storage area $\left(\mathrm{m}^{2}\right)$ and labour. However, the interviews conducted with the operational managers of MIP resulted in the exclusion of number of berths, storage area and labour inputs for container terminal operations and storage area and labour inputs for dry bulk terminal operations as the port had never encountered any shortage or congestion regarding these inputs. In light of this information, the following table presents input and output variables for both models.

Table 1. Input and Output Measures

\begin{tabular}{|l|l|l|}
\hline & Dry bulk terminal & $\begin{array}{l}\text { Container } \\
\text { terminal }\end{array}$ \\
\hline Output & $\mathrm{y}_{1}-1 /$ BTD & $\mathrm{y}_{1}-1 /$ BTD \\
\hline \multirow{5}{*}{ Input } & $\mathrm{x}_{1}-$ number of tugs & $\mathrm{x}_{1}-$ number of tugs \\
\cline { 2 - 3 } & $\begin{array}{l}\mathrm{x}_{2}-\text { number of } \\
\text { quay cranes }\end{array}$ & $\begin{array}{l}\mathrm{x}_{2} \text { - number of } \\
\text { quay cranes }\end{array}$ \\
\cline { 2 - 3 } & $\mathrm{x}_{3}-$ maximum draft & $\mathrm{x}_{3}$ - maximum draft \\
\cline { 2 - 3 } & $\mathrm{x}_{4}-$ berth length & $\mathrm{x}_{4}-$ berth length \\
\cline { 2 - 3 } & $\begin{array}{l}\mathrm{x}_{5}-\text { number of } \\
\text { berths }\end{array}$ & \\
\hline
\end{tabular}

DEA method is an efficiency measurement tool which postulates that the efficiency would increase as the value of output increases. As the model will assume the lower the BTD is the higher the performance would be, this data is included in the model as 1/BTD. In addition to this, operations with a greater BTD value than 20 days are considered as an indicator of shipowner related delays. For this reason such cases have been removed from the data set. The BTD is calculated as an annual average based on the below equation where $\mathrm{n}$ represents the total number of vessel calls.

$$
\text { Average BTD }=\frac{\sum_{1}^{n}(\text { Actual Berthing Time }- \text { Requested Berthing Time })}{n}
$$


Tug service is one of the more important port service that would effect the berthing performance of a terminal. Any shortage or drawback in this service can result in delays and decreasing efficiency. Between the years 2011-2014, the number of tugs in MIP were 4, whereas in the next year it increased to 5 .

Number of quay cranes is another important matter in berthing performance. As quay cranes' responsibility is of the highest order when it comes to handling operation, the number of cranes directly effects berth occupancy. Number of quay cranes in MIP dry bulk terminal were 4 throughout the time period covered by this study, while in container terminal the number of quay cranes have increased from 12 to 16 with the equipment investments made in May of 2015. In order to reflect this change into the annual data number of quay cranes have been weighted as number of quay cranes multiplied by months.

Draft of a berth is a deciding factor in limiting the size of the vessels that can be berthed in that specific terminal. In MIP, the maximum draft for dry bulk terminal is 14 meters, while the container terminal was treated to an upgrade from 14 meters to 15.5 meters as a part of the new quay building investment in 2014.

Berth length of a terminal is determinant in the size of the vessels that can call a terminal. Berth length, along with number of berths, are measures that decides berth availability. In this model the number of berth was not included in container terminal analysis for two reasons: (i) this input had not changed over the time period that is covered by this study, (ii) port representatives noted that there had never been performance deficiencies caused by number of berth number. However in the dry bulk terminal, berth number decreased from 14 to 12 , as the previously shared 3 berths were assigned exclusively for container handling in 2014. This change of assignment affected the berth length as well. The port's total berth length was 2160 meters through the years of 2011 to 2013. In 2014, the construction for expansion of the container terminal berths left the port with 1885 meters of berth length, which was followed by the completion of expansion, resulting in a total of 2385 meters in the year of 2015. Whereas in the dry bulk terminal, the total berth length was 2045 meters through the years 2011 to 2013, up until the assignment of 3 berths to container terminals, reduced this number to 1615 meters. Raw data for the above mentioned inputs can be summarized in the following table:

Table 2. Raw Data of Inputs and Outputs

\begin{tabular}{|c|c|c|c|c|c|c|c|c|c|c|c|c|}
\hline & \multicolumn{2}{|c|}{ 1/BTD } & \multicolumn{2}{c|}{$\begin{array}{c}\text { NUMBER OF } \\
\text { TUGS }\end{array}$} & \multicolumn{2}{c|}{$\begin{array}{c}\text { NUMBER OF } \\
\text { CRANES }\end{array}$} & \multicolumn{2}{c|}{$\begin{array}{c}\text { NUMBER OF } \\
\text { BERTHS }\end{array}$} & \multicolumn{2}{c|}{ BERTH LENGTH } & \multicolumn{2}{c|}{ DRAFT } \\
\hline Years & C & B & C & B & C & B & C & B & C & B & C & B \\
\hline 2011 & 0,1914 & 0,3780 & 4 & 4 & 144 & 4 & NI & 14 & 2160 & 2045 & 13 & 14 \\
\hline 2012 & 0,1279 & 0,2375 & 4 & 4 & 144 & 4 & NI & 14 & 2160 & 2045 & 13 & 14 \\
\hline 2013 & 0,1678 & 0,1581 & 4 & 4 & 144 & 4 & NI & 14 & 2160 & 2045 & 13 & 14 \\
\hline 2014 & 0,1781 & 0,0409 & 4 & 4 & 144 & 4 & NI & 12 & 1885 & 1615 & 15,5 & 14 \\
\hline 2015 & 0,1675 & 0,0675 & 5 & 5 & 164 & 4 & NI & 12 & 2385 & 1615 & 15,5 & 14 \\
\hline 2016 & 0,2138 & 0,0760 & 5 & 5 & 192 & 4 & NI & 12 & 2385 & 1615 & 15,5 & 14 \\
\hline
\end{tabular}

*NI=Not Included, C=Container Terminal, B=Dry Bulk Terminal 


\section{Results}

In this section, related data from the year 2011 to 2016 is evaluated by using DEA-CCR and DEA BCC models. Table 3 shows statistics of container and dry bulk terminals separately. DEA-CCR model reflects the results with the assumption of constant return to scale whilst DEABCC model represents the results with variable return to scale. In this study, as DMUs consist of years of a single port, CCR model, with its function on constant return to scale, is essential for the overall performance evaluation of the port and proves to be more useful for this study than BCC. Therewithal, with comparing the results acquired through BCC and CCR models would help identify overuse of port resources (inputs).

Table 3. Statistics Summary of DEA Analysis

\begin{tabular}{|c|c|c|c|c|}
\hline & \multicolumn{2}{|c|}{$\begin{array}{c}\text { Container } \\
\text { Terminal }\end{array}$} & \multicolumn{2}{c|}{$\begin{array}{c}\text { Dry Bulk } \\
\text { Terminal }\end{array}$} \\
\hline Years & CCR & BCC & CCR & BCC \\
\hline 2011 & 1,00 & 1,00 & 1,00 & 1,00 \\
\hline 2012 & 0,67 & 0,67 & 0,63 & 0,63 \\
\hline 2013 & 0,88 & 0,88 & 0,42 & 0,42 \\
\hline 2014 & 1,00 & 1,00 & 0,14 & 1,00 \\
\hline 2015 & 0,78 & 0,83 & 0,23 & 0,89 \\
\hline 2016 & 1,00 & 1,00 & 0,25 & 1,00 \\
\hline
\end{tabular}

Analyzing the results presented in Table 3 shows that the implemented investments of MIP, along with the shift in assignments of two of berths have significant effect on the efficiency. In container terminal, the most efficient DMUs are the years 2011, 2014 and 2016 both according to CCR and BCC models.

Between the years of 2011 to 2013, there seems to be a varying degree of decrease in the efficiency, due to do increase in BTD levels, with no change in inputs. The following year of 2014, is one of three most efficient DMUs. However, the main reason for its efficiency score stems from the decrease in berth length input. The implemented investments mentioned in the previous section started to reveal itself as increase in inputs in 2015. Albeit, when analyzed in mere efficiency perspective, the efficiency score decreased as the BTD levels increased along with those increasing inputs. In 2016, the increase in the quay crane number provided positive outcomes, achieving perfect efficiency and the lowest level of BTD among the compared years.

When the findings regarding the dry bulk terminal are analyzed, it is seen that the most efficient DMU in the CCR model is the year 2011. Whereas, according to BCC model, along with 2011, years 2014 and 2016 also have perfect efficiency scores. The year 2011, when compared with the rest has the lowest BTD level and highest level of inputs (except tug number). In the following two years, even though the input levels remained constant, BTD levels increased gradually. These results, along with the number of ship calls shown in Table 4 proves that there is indeed a decrease of efficiency in each input performance. Although this decrease of efficiency in the dry bulk terminal should be considered as an indicator of investment requirement in said terminal, as the container terminal was the main focus of investment, the number of berths assigned to dry bulk terminal was decreased to 12 from 14 as a result of assignment of the said berths to the container terminal in 2014. Consequently, according to the CCR model, the year 2014 stands out as the least efficient DMU. On the other hand, according to the BCC model, in context with the decrease in inputs, a higher score of efficiency was achieved. In the years 2015 and 2016, the small increase in the number of tugs, resulted in a similar small increase in efficiency scores. The fact that CCR efficiency scores are low while the BCC efficiency scores are high is an indicator that there is an overuse of resources in these years, similar to the year 2014 . 
Table 4. Annual Number of Ship Calls for Terminals

\begin{tabular}{|c|c|c|}
\hline Years & Container & Dry Bulk \\
\hline 2011 & 1361 & 1315 \\
\hline 2012 & 1463 & 1280 \\
\hline 2013 & 1538 & 1007 \\
\hline 2014 & 1543 & 1083 \\
\hline 2015 & 1437 & 765 \\
\hline 2016 & 1479 & 767 \\
\hline
\end{tabular}

As it can be seen from Table 4, the shift of inputs from dry bulk to container terminal resulted in longer BTD and consequently lesser ships calling the dry bulk terminal of the port. On the other hand, said inputs served the needs of the container terminal and helped keeping a steady number of vessel calls with minor fluctuations.

\section{Conclusion and Discussion}

DEA is a commonly used method in port performance measurement studies. Majority of the studies uses cargo throughput as output while analyzing port performance. However, aside from the cargo throughput, another significant yet understudied performance aspect which has an important effect on port selection is ship waiting time. In this study, BTD is selected as the output, since it covers the waiting time period that is fully related with the performance of the port. Application of this DEA to MIP allowed the authors to investigate the effects of investments on BTD, as MIP implemented various improvements on related inputs through the years.

Results show that, the container terminal which had a high level of efficiency in 2011, fell below this level throughout the process. Following the investments that include the increase of berth length, number of quay cranes, number of tugs and draft level, the needs arising from the increasing volume of cargo flow were met and high efficiency level was once again achieved.

However, in the dry bulk terminal, the high level of efficiency that was present in 2011 could not be maintained and suffered a significant decrease in terms of constant return to scale in the last three years, after the shift of assignments regarding length and number of berths to the container terminal. A crucial point that needs to be emphasized is that, even though the resources were used efficiently with the limited means at hand through these years, when compared with the year 2011 they still fall short. This situation also indicates an overuse of resources and has the potential of causing maintenance and depreciation costs. In order to cope with this problem, two strategies could be recommended; (i) investing on the inputs of the dry bulk terminal in parallel with investments made in container terminal, (ii) increasing the already present inputs' efficiency levels by optimizing their usage.

As a result, BTD efficiency has a significant role in service quality and directly affects the future selection decisions of port users. Especially in regions with heavy inter-port competition, this aspect of port efficiency comes out as a mean to gain competitive edge, because in the shipowners perspective, a port that handles their vessel faster, is a better port. In this regard, measuring port performance in BTD aspect proves to be a guide light for decision makers, helping with both evaluating their current position and future planning.

The main limitation of this research is the number of DMU's (years) which is caused by the availability of the recorded data. Another limitation is that, in similarity with the other studies in the literature, this study analyzed equipment based inputs solely on quantity, disregarding their specifications related with their performance.

For further researches, it is possible to carry out thorough investigations by using 
differing methodologies. For instance, super efficiency analysis, with providing the possibility to compare efficient DMUs against each other, offers a more detailed analysis. Another research suggestion might be the inclusion of more ports, enabling the usage of panel data for the efficiency comparison and benchmarking analysis among them.

\section{References}

[1] Notteboom, T. and Winkelmans, W. (2001). Structural changes in logistics: How will port authorities face the challenge?. Maritime Management and Policy, 28 (1): 71-89.

[2] Akbayirli, K., Deveci, D. A., Balci, G. and Kurtuluş, E. (2016). Container port selection in contestable hinterlands. Journal of ETA Maritime Science, 4(3): 249-265

[3] Saeed, N. and Aaby, B. C. (2013). An analysis of factors contributing as selection criteria for users of European container terminals. TRB 2013 Annual Meeting.

[4] Cullinane, K. and Wang, T. F. (2006). Data envelopment analysis (DEA) and improving container port efficiency. Research in Transportation Economics, 17: 517-566.

[5] Barros, C. P. (2003). The measurement of efficiency of Portuguese sea port authorities with DEA. International Journal of Transport Economics, 30 (3): 335-354.

[6] Lin, L. C. and Tseng, C. C. (2007). Operational performance evaluation of major container ports in the AsiaPacific region. Journal of Maritime Policy \& Management, 34 (6): 535551.

[7] Ng, A. S. F. and Lee, C. X. (2007). Productivity analysis of container ports in Malaysia: A DEA approach. Journal of Eastern Asia Society for Transportation Studies, 7: 2940-2952.
[8] Min, H. and Park, B. I. (2008). A hybrid data envelopment analysis and simulation methodology for measuring capacity utilization and throughput efficiency of container terminals. International Journal of Logistics Systems and Management, 4 (6): 650-672.

[9] Kamble, S. S., Raoot, A. D. and Khanapuri, V. B. (2010). Improving port efficiency: A comparative study of selected ports in India. International Journal of Shipping and Logistics, 2 (4): 444-470.

[10] Roll Y. and Hayuth Y. (1993). Port performance comparison applying data envelopment analysis (DEA). Journal of Maritime Policy \& Management, 20 (2): 153-161.

[11] Min, H.and Park, B. I. (2005). Evaluating the inter-temporal efficiency trends of international container terminals using data envelopment analysis. International Journal of Integrated Supply Management, 1 (3): 258-277.

[12] Barros, C. P. (2006). A benchmark analysis of Italian seaports using data envelopment analysis. Maritime Economics \& Logistics, 8 (4): 347-365.

[13] Ablanedo-Rosas, J. H. and Ruiz-Torres, A. J. (2009). Benchmarking of Mexican ports with data envelopment analysis. International Journal of Shipping and Transport Logistics, 1 (3): 276-294.

[14] Hung, S. W., Lu, W. M. and Wang, T. P. (2010). Benchmarking the operating efficiency of Asia container ports. European Journal of Operational Research, 203 (3): 706-713.

[15] Munisamy, S. and Singh, G. (2011). Benchmarking the efficiency of Asian container ports. African Journal of Business Management, 5 (4): 13971407.

[16] Rajasekar, T., Sania, A. P. and Malabika, D. P. (2014). Measurement of efficiency of major ports in India 
- A data envelopment analysis approach. International Journal of Environmental Sciences, 4 (5): 926936.

[17] Cullinane, K. P. B., Ji, P. and Wang, T. F. (2005). The relationship between privatization and DEA estimates of efficiency in the container port industry. Journal of Economics and Business, 57 (5): 433-462.

[18] Itoh, H. (2002). Efficiency changes at major container ports in Japan: A window application of data envelopment analysis. Review of Urban and Regional Development Studies, 14 (2): 133-152.

[19] Al-Eraqi, A. S., Mustafa, A., Khader, A. T. and Barros C. P. (2008). Efficiency of Middle Eastern and East African seaports: Application of DEA using window analysis. European Journal of Scientific Research, 23 (4): 597-612.

[20] So, S., Kim, J., Cho, G. and Kim, D. (2007). Efficiency analysis and ranking of major container ports in northeast Asia: An application of data envelopment analysis. International Review of Business Research Papers, 33 (2): 486-503.

[21] Ateş, A. and Esmer, S. (2013). Türk konteyner terminalleri üzerinde 2009 yll küresel finans krizinin etkileri. Sayistay Dergisi, 91: 105-125.

[22] Ateş, A. and Esmer, S. (2014). Farklı yöntemler ile türk konteyner limanlarının verimliliği, Verimlilik Dergisi, 2014 (1): 61-76.

[23] Güner, S. (2015). Proposal of a twostage model for measuring the port efficiency and an implication on Turkish ports. Alphanumeric Journal, 3(2): 99-106.

[24] Güner, S. (2015). Investigating infrastructure, superstructure, operating and financial efficiency in the management of Turkish seaports using data envelopment analysis.
Transport Policy, 40: 36-48.

[25] Charnes, A., Cooper, W. W. and Rhodes, E. (1978). Measuring the efficiency of decision making units. European Journal of Operational Research, 2 (6): 429-444.

[26] Farrell, M. J. (1957). The measurement of productive efficiency. Journal of the Royal Statistical Society, 120 (3): 253290.

[27] Banker, R. D., Charnes, A. and Cooper, W. W. (1984). Some models for estimating technical and scale inefficiencies in data envelopment analysis. Management Science, 30 (9): 1078-1092.

[28] Cook, W. D., Tone, K. and Zhu, J. (2014). Data envelopment analysis: Prior to choosing a model. Omega, 44: 1-4.

[29] Panayides, P. M., Maxoulis, C. N., Wang, T. F. and Ng, K. Y. A. (2009). A critical analysis of DEA applications to seaport economic efficiency measurement. Transport Reviews, 29 (2): 183-206. 